\title{
Analisis Kualitas Kinerja Aparatur Dalam Pelayanan Umum Pada Kantor Distrik Sorong Timur Kota Sorong Papua Barat
}

\author{
Rusdi Rusdi ${ }^{1}$, Saiful Ichwan ${ }^{2}$ \\ ${ }^{1,2}$ Program Studi Ilmu Pemerintahan, FISIP, Universitas Muhammadiyah Sorong, Indonesia \\ Email: rusdi@um-sorong.ac.id, saifulichwan@gmail.com
}

\begin{abstract}
ABSTRAK
Pelaksanaan Pelayanan pada Kantor distrik Sorong Timur dapat dilakukan dengan sistem manajemen dengan mengadakan pembinaan kelembagaan yang mengarah pada terciptanya iklim kondusif dan pelayanan yang berkualitas. Namun kenyataan yang terjadi di lapangan masih banyak pemerintahan dalam pelayanan tidak sesuai yang di harapkan. Penelitian ini bertujuan untuk mengetahui bagaimana upaya peningkatan kinerja pegawai dan faktor yang mendukung upaya peningkatan kinerja pegawai pada Distrik Sorong Timur, Penelitian ini menggunakan pendekatan kualitatif dengan teknik analisis data deskriptif kualitatif dengan metode pengumpulan data dengan wawancara, angket dan dokumentasi. Hasil data menunjukkan bahwa 44\% tanggapan masyarakat secara keseluruhan berada pada jawaban Cukup baik, dari penelitian ini menunjukkan peningkatan kinerja pegawai pada kantor distrik sorong timur telah dilaksanakan secara cukup baik sehingga capaian kinerja program dan kegiatan dapat diselesaikan dengan baik . Pelaksanaan Pelayanan pada Kantor distrik Sorong Timur dapat dilakukan dengan sistem manajemen dengan mengadakan pembinaan kelembagaan yang mengarah pada terciptanya iklim kondusif dan pelayanan yang berkualitas
\end{abstract}

Keywords : Kualitas; Kinerja; Pelayanan Umum

\begin{abstract}
Service delivery in the East Sorong district office can be done with a management system by organizing institutional guidance that leads to the creation of a conducive climate and quality services. But the reality that happens on the ground is that there are still many governments whose services are not as expected. This study aims to determine how efforts to improve employee performance and factors that support efforts to improve employee performance in East Sorong District, This study uses a qualitative approach with qualitative descriptive data analysis techniques with data collection methods with interviews, questionnaires and documentation. The results of the data show that $44 \%$ of the public response overall is on the answer Good enough, from this study shows an increase in employee performance at the East Sorong District Office has been carried out quite well so that the performance of programs and activities can be completed well. Service delivery in the East Sorong district office can be done with a management system by organizing institutional guidance that leads to the creation of a conducive climate and quality services
\end{abstract}

Kata kunci : Quality of performance; Service; Government Apparatus 


\section{PENDAHULUAN}

Perbaikan dalam penyelenggaraan pemerintah Distrik harus dilakukan, terutama bagaimana menumbuhkan dan meningkatkan kinerja aparat kantor Distrik. Sebagai pelayan masyarakat harus wajib memberikan atau mengupayakan pelayanan yang baik dan juga sebagai abdi negara harus berupaya semaksimal mungkin karena sebagai tugas yang di berikan oleh pemerintah. Sedangkan masyarakat hanya dapat menilai kinerja kantor Distrik dari kualitas pelayanan yang diterimanya.

Sehubungan dengan jumlah aparat kantor Distrik yang minim atau tidak sebanding dengan beban kerja yang diterima, utamanya dalam hal pelayanan yang baik kepada masyarakat, maka perlu dilakukan peningkatan kinerja aparat kantor Distrik sorong timur terhadap pelayanan kepada masyarakat demi tercapainya pelayanan yang baik dari kantor Distrik

\section{Kinerja aparat kantor Distrik} sorong timur yang cukup tinggi diharapkan dapat mewujudkan suatu efektifitas dalam penyelenggaraan pemerintah Distrik sorong timur sebagai bentuk kesiapan aparat kantor Distrik dalam mengadapi perubahan-perubahan yang terjadi dalam masyarakat. Peningkatan kualitas pelayanan yang menjadi tuntutan masyarakat harus dipenuhi oleh aparatur Distrik sorong timur sebagai penyelenggara pemerintah di Distrik Karena pada dasarnya menerima pelayanan yang memuaskan dari aparat pemerintah merupakan hak yang dimiliki setiap warga masyarakat. Dengan pelayanan yang diterima tersebut maka diharapkan masyarakat akan berpartisipasi aktif dalam mendukung tugas-tugas aparat pemerintah, sehingga terjadi keseimbangan antara hak yang ditetapkan oleh masyarakat dan kewajiban yang harus dijalankan sebagai warga Negara.

$$
\text { Potret buram kinerja }
$$
aparat pelayanan publik diklaim sebagai salah satu dari penyebab faktor-faktor yang menjadi kendala dalam perbaikan dan peningkatan kualitas pelayanan publik. Pelayanan yang bertele-tele dan cenderung birokratis, biaya yang tinggi, pungutanpungutan tambahan, perilaku aparat yang lebih bersikap sebagai pejabat ketimbang abdi masyarakat, pelayanan yang diskriminatif, dan sederetan persoalan lainnya merupakan beberapa indikasi yang tidak dapat dipungkiri.

Tujuan penelitian secara umum adalah untuk mengetahui kualitas kinerja aparatur pemerintah di Kantor Distrik Distrik 
Sorong Timur dalam memberikan pelayanan kepada masyarakat, sedangkan secara khusus adalah sebagai berikut:

1. Untuk mengetahui kualitas kinerja pemerintah di Kantor Distrik Sorong Timur dalam memberikan pelayanan kepada masyarakat.

2. Untuk mengetahui upaya yang dilakukan dalam meningkatkan kinerja aparat Kantor Distrik Sorong Timur dalam memberikan pelayanan kepada Masyarakat.

3. Untuk mengetahui faktor-faktor yang mempengaruhi kualitas kinerja aparatur pemerintah dalam memberikan pelayanan kepada masyarakat di Kantor Distrik Kota Sorong.

\section{METODE}

Penelitian ini menggunakan Jenis Penelitian deskriptif kualitatif berdasarkan pada wawancara berbasis tugas (the taskbased interview). data yang dianalisis adalah hasil Kuesioner yang diisi oleh responden. Oleh karena itu, penelitian kualitatif ini sebagai prosedur untuk menganalisis kualitas kinerja aparatur pemerintahan dalam pelayanan umum kantor distrik sorong timur kota sorong papua barat.

Instrumen yang digunakan untuk mengumpulkan data dan informasi pada penelitian ini meliputi: Kuesioner, Wawancara (interview) , Observasi, Dokumentasi.

Teknik pengumpulan data melalui dokumentasi dimaksudkan untuk memperoleh data yang didapat dengan jalan mempelajari dokumen-dokumen yang ada di Kantor Distrik Sorong timur.

Teknik analisis data penelitian ini menggunakan teknik analisa deskriptif dan kuantitaf, yaitu dengan cara mempresentasekan jawaban pada setiap hasil wawncara untuk mengetahui kategori jawaban informan terhadap pelayanan di Kantor Distrik sorong timur kota sorong.

Untuk data yang diolah dan dinilai dengan cara mentabulasi setiap jawaban yang diberikan informasi kemudian dianalisa secara deskriptif sesuai dengan tujuan penelitian. Teknis analisis data yang digunakan adalah presentase dan kategori teknik presentasi yaitu dengan menggunakan rumus:

$$
\mathrm{P}(\%)=\mathrm{F} / \mathrm{N} \times 100 \%
$$

\section{HASIL DAN PEMBAHASAN}

Hasil jawaban responden (masyarakat) secara keseluruhan terhadap pelayanan yang diberikan aparatur di Kantor Distrik Sorong Timur Kota Sorong dapat dilihat pada table 1 berikut ini : 
Tabel 1. Rekapitulasi jawaban responden terhadap pelayanan di Kantor Distrik Sorong Timur Kota Sorong

\begin{tabular}{|c|c|c|c|c|}
\hline No & Indikator Penilaian & $\mathrm{B}$ & $\mathrm{C}$ & $\mathrm{K}$ \\
\hline 1. & $\begin{array}{l}\text { Kesederhanaan dalam } \\
\text { pelayanan }\end{array}$ & 35 & 10 & 5 \\
\hline 2. & $\begin{array}{l}\text { Kejelasan dan } \\
\text { Kepastian dalam } \\
\text { pelayanan }\end{array}$ & 30 & 15 & 5 \\
\hline 3. & $\begin{array}{l}\text { Keamanan dalam } \\
\text { pelayanan }\end{array}$ & 25 & 18 & 7 \\
\hline 4. & $\begin{array}{l}\text { Keterbukaan dalam } \\
\text { pelayanan }\end{array}$ & 15 & 27 & 8 \\
\hline 5. & $\begin{array}{l}\text { Efesiensi dalam } \\
\text { pelayanan }\end{array}$ & 8 & 29 & 13 \\
\hline 6. & $\begin{array}{l}\text { Ekonomi dalam } \\
\text { pelayanan }\end{array}$ & 10 & 26 & 14 \\
\hline 7. & $\begin{array}{l}\text { Keadilan yang merata } \\
\text { dalam pelayanan }\end{array}$ & 14 & 27 & 9 \\
\hline 8. & $\begin{array}{l}\text { Ketepatan waktu } \\
\text { dalam pelayanan }\end{array}$ & 12 & 24 & 14 \\
\hline
\end{tabular}

$149 \quad 176 \quad 75$

\section{Jumlah jawaban}

$37,2 \quad 44 \quad 18,7$

$\begin{array}{llll}\text { Presentase ( \% ) } & 5 \% & \% & 5 \%\end{array}$

Sumber data dari hasil pengolahan Jawaban 50

Responden

Menurut tanggapan masyarakat secara keseluruhan berdasarkan table 12 diatas bahwa 149 jawaban baik atau sebesar 37,25\%. Sedangkan 176 atau sebesar $44 \%$ yang memberikan jawaban cukup. Sedangkan 75 atau 18,75\% yang memberikan jawaban kurang. Dari hasil ini dapat dikatakan bahwa aparatur Kantor Distrik Sorong Timur Kota Sorong dalam kualitas kinerja dalam memberikan pelayanan kepada masyarakat termasuk dalam kategori yang cukup baik.

Hal ini membuktikan bahwa pelayanan di Kantor Distrik Sorong Timur Kota Sorong masih perlu ditingkatkan. Terutama dalam hal penambahan personil, peningkatan tingkat pendidikan ataupun diklat dan penyediaan sarana dan prasarana atau alat bantu lainnya. Dengan terpenuhnya kekurangan tersebut maka pelayanan optimal akan terwujud.

Kualitas kinerja aparatur Kantor Distrik Sorong Timur Kota Sorong dalam pelayanan masyarakat secara keseluruhan menurut pandangan masyarakat dinilai Cukup Baik. Dengan indikator yaitu kesederhanaan, kejelasan dan kepastian, keamanan, keterbukaan, efesiensi, keadilan yang merata dan ketepatan waktu dalam pelayanan.

Berdasarkan hasil wawancara penulis dengan aparatur Kantor Distrik Sorong Timur Kota Sorong pada saat melakukan penelitian diungkapkan bahwa Distrik sering memberikan kata-kata pujian yang disampaikan kepada aparaturnya apabila telah menyelesaikan suatu tugas dan tanggung jawab sesuai dengan rencana yang telah ditetapkan dan tujuan yang diharapkan. Tindakan Distrik tersebut menimbulkan rasa banga dan merasa dihargai sebagai seorang bawahan. Dengan 
demikian aparatur kantor Distrik akan termotivasi untuk bekerja lebih baik. Selain itu berdasarkan pengamatan yang dilakukan penulis pada saat pelaksanaan penelitian dapat diketahui bahwa Distrik selalu memberikan motivasi kepada aparatur Kantor Distrik Sorong Timur Kota Sorong yang akan turun ke lapangan untuk melihat langsung kondisi masyarakat di Kantor Distrik Sorong Timur Kota Sorong

Faktor-faktor yang mempengaruhi kualitas aparatur Kantor Distrik Sorong Timur Kota Sorong di atas menurut analisis penulis secara keseluruhan masih perlu ditingkatkan yaitu pendidikan dan latihan aparatur, sarana, pengawasan, dan motivasi guna menunjang pelayanan yang diberikan.

Distrik selaku pimpinan mengawasi jalannya proses pelaksanaan yang dibebankan kepada perangkat. Upaya yang ditempuh adalah sebagai berikut:

1. Meningkatkan disiplin waktu, yakni adalah jenis disiplin yang paling mudah dilihat dan dikontrol. Mengenai disiplin terhadap jam kerja misalnya melalui system pendaftaran absensi yang baik atau system apel, dapat dipantau secara cepat dan tepat.

2. Meningkatkan disiplin kerja, kedisiplinan merupakan komponen yang mutlak harus dimiliki oleh seorang pegawai. Jika seorang pegawai telah memiliki kedisiplinan kerja yang tinggi, setiap tugas yang diberikan kepadanya akan dilaksanakan dengan penuh tanggung jawab. Karena adanya tanggung jawab terhadap tugas yang diberikan, maka hasil dari suatu pekerjaan akan dicapai dengan maksimal.

3. Menyelenggarakan rapat staf, yakni Distrik secara rutin atau insidentil menyelenggarakan rapat staf atau pertemuan dalam rangka mengawasi dan mengetahui pelaksanaan tugas dan fungsi pemerintahan yang dilakukan oleh aparatur Distrik.

4. Prinsip pembagian tugas, dengan prinsip ini setiap pegawai memiliki tugas, wewenang dan tanggung jawabnya masing-masing berdasarkan struktur organisasi yang ada. Dengan demikian seorang pegawai mempunyai nilai tersendiri dan dapat diarahkan oleh Distrik Sorong Timur selaku pimpinan.

5. Membuat rencana kerja harian, yakni setiap kegiatan akan berhasil dengan baik jika dilakukan melalui perencanaan yang matang. Dengan adanya rencana kerja harian aparatur tidak merasa bingung karena mengetahui dengan jelas apa yang harus dikerjakan. 
6. Memeriksa laporan hasil pekerjaan yang menjadi tugas aparatur harus dilaporkan kepada Distrik selaku pimpinan. Laporan hasil pekerjaan dari aparatur kepada Distrik sangat penting untuk mengetahui hasil kerja bawahannya. Untuk selanjutnya diambil langka-langka dan kebijaksanaan guna meningkatkan hasil pekerjaan kearah yang lebih baik.

\section{SIMPULAN}

Berdasarkan analisis data maka dapat diambil kesimpulan sebagai berikut:

1. Pelayanan yang diberikan oleh aparatur Kantor Distrik Sorong Timur Kota Sorong pada umumnya berdasarkan hal tersebut di atas sudah sesuai oleh prosedur yang telah ditetapkan. Tetapi walaupun demikian masyarakat masih menginginkan adanya perbaikan kualitas dalam pelaksanaan pelayanan. Hal ini tampak dari jawaban responden yang secara umum memberikan jawaban pada kategori cukup pada pemberian pelayanan kepada masyarakat oleh aparatur pemerintah di Kantor Distrik Sorong Timur Kota Sorong

2. Faktor yang mempengaruhi kualitas kinerja aparatur Kantor Distrik Sorong Timur Kota Sorong adalah (1)

Kurangnya Pendidikan dan latihan aparatur Kantor Distrik; (2) Minimnya jumlah sarana yang tersedia;

Kurangnya pengawasan; serta kurangnya motivasi.

3. Upaya-upaya yang akan dilakukan dalam meningkatkan kualitas kinerja aparatur pemerintah di Kantor Distrik Sorong adalah sebagai berikut:

a. Memberikan kesempatan aparatur pemerintah di Kantor Distrik Sorong Timur Kota Sorong untuk mengikuti berbagai pendidikan dan latihan.

b. Menyediakan fasilitas atau sarana.

c. Melakukan pengawasan oleh Distrik selaku pimpinan Kantor Distrik Sorong Timur Kota Sorong terhadap aparatur pemerintah

\section{UCAPAN TERIMA KASIH}

Peneliti mengucapkan terima kasih kepada Direktorat riset dan Pengabdian Masyarakat, Direktorat Jenderal Penguatan Riset dan Pengembangan Kementerian Riset, Teknologi dan Pendidikan Tinggi

\section{DAFTAR PUSTAKA}

Mustafa, W. (2015). Kinerja Aparat Kantor Camat Memberikan Pelayanan Administrasi Kepada Masyarakat Di Kecamatan Blangpidie Aceh Barat Daya. Publikauma: Jurnal Administrasi Publik Universitas Medan Area, 3(1), 40-53.

Rukayat, Y. (2018). Kualitas Pelayanan Publik Bidang Administrasi 
Kependudukan Di Kecamatan Pasirjambu. Jurnal Ilmiah Magister Administrasi, 11(2).

Rusdi, R. (2018). Pengaruh Kepemimpinan dan Komunikasi Terhadap Kinerja Pegawai pada Kantor Kecamatan Bacukiki Barat Kota Parepare. Jurnal Noken: Ilmu-Ilmu Sosial, $3(1), 48-61$

Sulistya, A. D. (2008). Profesionalisme Aparatur Pemerintah (Studi Kasus Responsifitas dan Inovasi Aparatur di Kecamatan Sumber Kabupaten Rembang) (Doctoral dissertation, program Pascasarjana Universitas Diponegoro).

Syanputri, F. (2009). Analisis Pengaruh Kepuasan Kerja terhadap Kinerja Tenaga Kependidikan (Studi Kasus: Sembilan Fakultas Institut Pertanian Bogor, Darmaga Bogor). 